\title{
A Study on the Traditional Folk Culture in Preschool Education
}

\author{
Luoyao Fang
}

School of Education \& Management, Yunnan Normal University, Kunming, 650500, China 15087147221@163.com

\begin{abstract}
Folk culture is not only the important factor of human's growing circumstances, but also the fount of spiritual resources. Folk culture can helps promoting the growth of human as the foundation of education. The role of folk culture which plays in preschool education is more and more important. Since the stage of preschool education is vital for the growing of children psychology and action, when the education of traditional folk culture is introduced, it can make a huge difference on fostering the perfect mental personality of preschool children. On the other hand, the introduction of the education of traditional folk culture is conductive to preschool education courses. Besides, the education of traditional folk culture can help to build a socialism harmonious society and establish socialism spiritual culture. What's more, it can strengthen preschool children sense of identity and responsibility toward the national culture.
\end{abstract}

Keywords: folk-custom; culture; preschool; education.

\section{传统民俗文化在学前阶段教育的研究}

\author{
方珞瑶 \\ 云南师范大学, 教育科学与管理学院, 昆明, 中国
}

摘 要: 民俗文化是人类成长环境中的重要因素, 也是人类汲取精神财富的源泉和宝库。民俗 文化作为教育根基促进人的成长，而在儿童早期教育中，民俗文化教育的重要性日渐显著。 学前教育阶段是儿童心理、行为发展的重要阶段, 传统民俗文化教育的引入对学前儿童健全 心理人格的培养具有重大影响, 对学前教育课程的开展具有重要意义, 有利于构建社会主义 和谐社会，也有利于树立社会文化新风，加强对民族文化的认同感和使命感。

关键词: 民俗;文化; 学前; 教育

\section{1. 前言}

民俗文化是劳动人民一代一代共同创造的精神文化成果，也是一种相对于官方的在生产 生活过程中形成的一系列的物质精神的文化现象。五千年历史长河, 民俗文化在智慧的劳动 人民手中传承与发展。“人民生活在民俗当中, 就像鱼类生活在水里一样。[1]”学前阶段民俗 文化的早教育尤为重要。

\section{2. 中国目前学前教育的现状}

目前, 我国学前教育的发展依然面临资金不足, 资源分配不均, 师资质量不高、力量不 足等问题。学前教育的发展主要依靠政府大力投资支持为主, 公办和民办幼儿园并举, 这一 举动一定程度上缓解了我国学前教育的资源不足的压力。在努力提升我国幼儿园硬件设施的 同时, 幼儿园内部的教学质量同样成为提升我国学前教育质量的重要内容。而在现阶段, 部 分幼儿园面临教学课程创新难题, 这是在提升我国学前教育质量的一个重要问题, 也是我国 学前教育发展到了一定阶段的表现。在本土社会文化上发展起来的学前教育文化, 同样应当 立足于优秀的社会文化之中。学前教育文化需要两个深化, 第一个是向外拓展型深化, 以批 判性地接受外来学前教育文化, 结合本国基本社会文化背景来进行课程实践; 第二个是向内 
深入型优化, 以继承发展, 开拓创新的眼光来看待本土文化资源, 利用好本土文化资源, 不 断丰富和提升学前教育课程文化质量。

\section{3. 民俗文化对学前阶段教育的价值与意义}

学前教育的发展在各国国家均具有其普遍性和特殊性。中华文化求同存异, 兼收并蓄的 特点, 为我国学前教育阶段对民俗文化的吸收与发展也产生了一定程度的影响。初期, 学前 教育的思想散见于各国书籍之间, 而后期西方文明先系统化、理论化将教育思想转化为实践 行动。但在中国, 直到 1923 年陈鹤琴创办了第一所幼儿教育实践中心一一南京鼓楼幼稚园, 我国的学前教育才刚刚开始付诸实践。而在我国第一所幼儿教育实践中心创办之前, 在幼儿 园普及之前, 甚至是幼儿园普及之后, 学前教育阶段的主导文化模式主要由民俗文化承担。 有人将民俗定义为满足一定群体的物质需求和行为需求的传统的行为模式。这种传统的行为 模式是相对于官方和科学, 其自身更加注重信仰和情感。从普遍性的角度, 在世界文化多元 化的背景之下, 中国学前教育对外来优秀学前教育思想和行为方式的接收, 国内外学前教育 文化日渐共通。从特殊性的角度, 伴随着中国民俗文化的发展, 中国学前教育文化有具有其 多样化的一面。我国民俗文化的多样性一定程度上也增加了学前教育文化内容的多样性。比 如开展民俗文化课程中民间歌谣、民间舞蹈、民间游戏、民间节日风俗等等。在我国民族多 样化的环境来说, 不同民族由于地理环境的不同形成了不同的民风民俗。在学前教育阶段, 新疆儿童们开始让自己能歌善舞; 内蒙孩子们从小练习摔跤, 逐渐形成勇猛威武的性格, 由 此看来, 学前教育阶段孩子们并不是死板的接受教育, 而是在一种寓教于乐的情景下, 民俗 文化发挥文化环境育人的作用, 对儿童早期教育产生了积极的影响。民俗文化深入学前阶段 教育, 让不同区域的学前教育文化普遍性扩大的同时, 特殊性也在变得愈加与众不同。中华 文化发展和沉淀经历过一个较长的阶段, 日渐成熟的民俗文化早已和我们生活息息相关, 从 学前阶段开始接触民俗文化有利于儿童日后社会健全人格的发展和全方位价值观的培育。

\section{4. 学前教育民俗文化课程的开展对民俗文化的影响}

随着民俗文化热潮的冷却, 民俗文化贴近学习生活作为文化课程的开展已经成为一种必 然趋势。学前教育阶段开展民俗文化课程, 是对民俗文化的一种重视, 同时也是对民俗文化 的一种传承与发展。学前教育民俗文化课程在其内容上, 主要突出表现在游戏活动、体育竞 技、音乐舞蹈和节日庆典礼仪等几个方面。儿童学习重点要在玩中学, 学中乐, 民俗文化课 程的增加符合儿童文化课程的需要。在日常的生活中, 教师将民俗文化有趣味性的增加进入 课程学习和娱乐活动之中, 孩子们在一种富有趣味性的环境下更容易接受民俗文化。例如在 课间活动时, 开展一些民俗性强的民间游戏; 在体育课上, 老师带领孩子进行一些特色体育 项目; 在艺术课上，民间歌曲和民间舞蹈也适当性的加入; 而在平常的节日庆典时，丰富儿 童的节日文化知识, 增加节日特色的民间庆祝活动。这些民俗文化课程的开展, 对于我国民 俗文化日渐流失的现象有一定的缓和作用。幼儿教师们在开展民俗文化课程时, 首先必须增 加自己民俗文化的储备量, 然后一部分课程以创新的手法和形式展现, 大大增强了民俗文化 的接受性, 趣味性, 也扩大了民俗文化的传播范围, 更新了民俗文化的传播形式。同时学前 阶段文化教育将会潜移默化、深远持久对儿童的一生产生影响。这种由低龄向高龄深入的民 俗文化阶梯型文化传播模式, 让我国的民俗文化的传承形成了一定程度上的良性循环。民俗 文化与我们的生活息息相关, 但在我国现在却面临挑战, 出现这种挑战的原因恰恰说明了我 国民俗文化是已经发展到了一定阶段的比较成熟的产物。挑战一方面来自于民俗文化是否能 选择性继承, 另一方面则来自于民俗文化是否能创造性发展。学前阶段的民俗文化课程较早 的将民俗文化引入孩子的世界, 家庭、学校、社会以及国家都能更早的对民俗文化课程引起 重视，对民俗文化传承方式和创新发展方式更早的开始实践和探索发展。 


\section{5. 结论}

民俗文化和学前教育, 二者相互关联, 密不可分, 民俗文化是学前教育阶段的重要内容, 学前教育阶段是民俗文化传播的重要阶段。近些年来, 学习传统文化的积极性日渐低迷, 与 国家致力于高举文化旗帜有所背离。重视学前教育阶段传统民俗文化教育的发展, 符合我国 发展社会主义文化的需要, 也符合世界文化多元性的需要。

\section{References}

[1] Zhao Haiyan. A Study on the Curriculum of Folk - custom Culture in Pre - school Education. Xinan University. 2012.

[2] Ye Miaoyun. On the Developmental Value of Preschool Education and Culture Curriculum. New Course. 2013. No9.p18-19.

[3] Duan Lianhua. On the Exploitation and Utilization of Folklore Curriculum Resources in Preschool Education. China Science and Education Innovation Guide. Science \& Technology Education Forum. 2013. No24. p191.

[4] Zhang Hong Kindergartens in Three Cultures. Early Childhood Education. Expert Interview. 2010. No30.

[5] Yan Yhonglian Preschool Education Concepts Reconstruction Movement in China. Early Childhood Education. 2007 No7-8. 